\title{
ASUPAN SERAT DAN MAGNESIUM DENGAN KADAR GLUKOSA DARAH PADA PASIEN DIABETES MELLITUS TIPE II
}

\author{
Olga Lieke Paruntu ${ }^{1}$, Nonce Nova Legi ${ }^{2}$, I Made Djendra ${ }^{3}$, Giantry Kaligis ${ }^{4}$ \\ Jurusan Gizi Poltekkes Kemenkes Manado \\ Email korespondensi : noncenovalegi@gmail.com
}

\begin{abstract}
Diabetes mellitus is very influential on the quality of human resources and has a significant impact on health costs. This diabetes mellitus cannot heal but can only be controlled. Patients with diabetes mellitus are not able to produce enough insulin or do not use it effectively so that there is excess glucose in the blood. One of the factors that triggers glucose is an unhealthy diet such as rarely consuming fiber, as well as consuming micronutrients, including magnesium. The general objective of this study was to determine the effect of fiber and magnesium intake with fasting blood glucose levels in type 2 diabetes mellitus patients at Pancaran Kasih General Hospital GMIM Manado. This research method using cross sectional design by purposive sampling. Data collection about the intake of fiber and magnesium using the 24-hour recall and the results of the examination of fasting blood glucose levels were taken through the medical record of the patient. Analyst data using logistic regression analysis. Based on data analysis using Fisher's Exact Test, showed $P$ value $=<0.05 / P=0.013$ means that there is a relationship between fiber intake and fasting blood glucose levels. While the results of data analysis using Fisher's Exact Test, showed $P$ value $=>0.05 / P=0.61$, meaning that there was no correlation between magnesium intake and fasting blood glucose levels. It can be concluded that there is a relationship between fiber intake and blood glucose levels. There is no relationship between magnesium intake and fasting blood glucose levels.
\end{abstract}

Key Words: Intake Of Fiber, Magnesium, Dibetes Mellitus

\section{PENDAHULUAN}

Penyakit diabetes mellitus sangat berpengaruh terhadap kualitas sumber daya manusia dan berdampak pada biaya kesehatan yang cukup besar. Insiden dan prevalensi penyakit ini tidak pernah berhenti mengalir terutama di negara sedang berkembang dan negara yang terlanjur memasuki budaya industrialisasi (Arisman,2013). Perkiraan prevalensi diabetes melitus secara global adalah 9.1 juta orang, Indonesia menjadi negara dengan populasi penderita terbanyak ke-5 di dunia (PERKENI,2015). Berdasarkan Hasil Risat Kesehatan Dasar tahun 2013 menunjukkan bahwa prevalensi diabetes melitus di Indonesia sebesar 1.5 dengan yang tertinggi terdapat di DI Yogyakarta sebesar 2.6\% dan terendah terdapat di lampung yaitu sebesar $0.7 \%$. Khusus di provinsi Sulawesi utara prevalensi tertinggi 
terdapat di kota Tomohon dan terendah di Minahasa Selatan. Kota Manado termasuk kota kedua tertinggi dari Kota Tomohon yaitu 3.2\%.

Perubahan pola makan yang tidak sehat dan konsumsi serat yang rendah mempercepat peningkatan kadar gula darah pada Diabetes Melitus Tipe 2. Semakin rendah asupan serat maka semakin tinggi kadar gula darah. WHO menganjurkan asupan serat adalah 25-30 gram/orang/hari. Sifat serat yang tidak dapat di cerna oleh tubuh membantu mengatasi rasa lapar dan memberikan rasa kenyang lebih lama sehingga menunda rasa lapar dan membuat seseorang tidak sering makan. Rata- rata konsumsi serat orang Indonesia kurang dari yang di anjurkan. Berdasarkan Angka Kecukupan Gizi (AKG) tahun 2013, anjuran serat rata-rata orang Indonesia sebesar $30 \mathrm{~g} / \mathrm{orang} / \mathrm{hari}$.

Selain zat gizi makro yang mempengaruhi kadar gula darah, ternyata ada juga zat gizi mikro yang mempengaruhi kadar gula darah yaitu diantaranya magnesium. Magnesium merupakan mikromineral yang memegang peranan penting pada homoostatis glukosa kerja insulin. Mengurai keterkaitan antara defisiensi magnesium dan diabetus sama sulitnya. Dalam keadaan hiperglisemia berat berat (terutama jika situasi ini telah berlangsung lama), ginjal tidak mampu menahan magnesium. Kehilangan magnesium ke dalam urin dalam jumlah besar menyebabkan penurunan kadar magnesium darah. Kenyataannya magnesium dan insulin saling membutuhkan satu sama lain. Tanpa magnesium, kelenjar pankreas tidak akan mampu menghasilkan cukup insulin, atau insulin yang disekresikan tidak bakal efisien dalam mengawasi glukosa darah. Selain itu, tanpa insulin magnesium tidak mungkin berhasil terangkut dari pembuluh darah ke dalam sel tempat mineral ini bekerja (Arisman,2013). Penelitian ini bertujuan untuk mengetahui hubungan antara asupan serat dan magnesium dengan kadar glukosa darah puasa pada pasien diabetes melitus tipe 2 rawat inap di RSU GMIM Pancaran Kasih Manado

\section{METODE}

Jenis penelitian ini adalah observasi, dengan pendekatan cross sectional..Populasi dalam penelitian ini adalah pasien Diabetes Melitus Tipe II yang berjumlah 34 pasien. Definisi operasional dalam penelitian ini yaitu Penderita diabetes melitus tipe 2 adalah pasien rawat inap terdiagnosa menderita DM Tipe 2 oleh Dokter, di RSU GMIM Pancaran Kasih Manado menggunakan skala ukur Ordinal, Asupan Serat adalah jumlah serat yang berasal dari makanan yang dikonsumsi oleh pasien diabetes mellitus tipe 2 rawat inap yang diperoleh melalui metode recaal $1 \times 24$ jam selama 3 hari berturut-turut. Dikategori baik bila $\geq 25 \mathrm{~g} / \mathrm{hari}$ dan kurang bila $<25 \mathrm{~g} / \mathrm{hari}$ menggunakan skala ukur ordinal. Asupan Magnesium adalah asupan zat gizi mikro magnesium dari bahan makanan/diet yang di konsumsi pasien selama dirawat. Indikator kecukupan magnesium menurut Angka Kecukupan Gizi (AKG), 2013 sebagai berikut : Dikategori baik bila $\geq 350 \mathrm{mg} / \mathrm{hari}$ dan kurang bila $<350 \mathrm{mg} / \mathrm{hari}$, menggunakan skala ukur ordinal. Asupan Magnesium adalah asupan zat gizi mikro magnesium dari bahan makanan/diet yang di konsumsi pasien selama dirawat. Indikator kecukupan magnesium menurut Angka Kecukupan Gizi (AKG), 2013 sebagai berikut : Dikategori baik bila $\geq 350 \mathrm{mg} /$ hari dan kurang bila $<350 \mathrm{mg} / \mathrm{hari}$. 
HASIL

\section{Kadar Glukosa Darah Puasa}

Tabel 1.. Kadar Glukosa Darah Puasa Pasien Diabetes Mellitus Tipe 2

\begin{tabular}{ccc}
\hline Kadar Glukosa Darah Puasa & $\mathrm{n}$ & $\%$ \\
\hline Normal $(80-125 \mathrm{mg} / \mathrm{dl})$ & 12 & 35 \\
Lebih $(>125 \mathrm{mg} / \mathrm{dl})$ & 22 & 65 \\
\hline Total & 34 & 100
\end{tabular}

Hasil menunjukan bahwa ada sebanyak 12 responden (35.3\%) memiliki kadar glukosa darah yang normal dan 22 orang responden (64.7\%) memiliki asupan kadar glukosa darah lebih. Menurut Marya (2013), pemeliharaan kadar glukosa darah dalam kisaran yang normal sangat penting bagi kelangsungan hidup mengingat glukosa plasma merupakan bahan bakar dominan untuk system saraf pusat. Jumlah glukosa dalam darah tergantung kepada keseimbangan antara jumlah yang masuk dan yang keluar.

Kadar glukosa darah puasa (BSG ${ }^{1}$ ) nuchter yang normal berkisar 3-5 mmol/1 (atau sekitar 80-120 mg/100 ml). Kadar ini akan meningkat mencapai nilai maksimal $8 \mathrm{mmol} / 1$ (atau sekitar $200 \mathrm{mg} / 100 \mathrm{ml}$ ) pada jam pertama setelah mengkonsumsi glukosa. Kenaikan kadar glukosa darah ini diubah oleh kerja insulin yang dihasilkan sebagai reaksi terhadap penningkatan kadar glukosa darah. Pada akhir 2 jam setelah konsumsi glukosa (atau 2 jam postprandial), kadar glukosa darah mulai kembali kepada nilai nucher atau nilai BSG puasa ( Beack, 2011).

\section{Asupan Serat}

Tabel 2. Asupan Serat Pasien Diabetes Mellitus Tipe 2

\begin{tabular}{ccc}
\hline Klasifikasi & $\mathrm{n}$ & $\%$ \\
Asupan Serat & & 73.5 \\
\hline Kurang $(<25$ g/hari) & 25 & 26.5 \\
Baik $(\geq 25$ g/hari) & 9 & \\
\hline Total & 34 & 100 \\
\hline
\end{tabular}

Hasil menunjukan bahwa ada sebanyak 9 responden (26.5\%) memiliki asupan serat yang baik dan 25 orang responden (73.5\%) memiliki asupan serat kurang. Menurut Perkumpulan Endokrinologi Indonesia (PERKENI) tahun 2011, menganjurkan Asupan serat yang baik bagi pasien diabetes melitus di Indonesia sebanyak \pm 25 gram. Begitu juga dengan Asosiasi Diabetes Amerika menganjurkan konsumsi serat sebanyak 20-35 gr/hari untuk penderita diabetes.

Serat merupakan karbohidrat kompleks dan disebut sebagai polisakarida yang bukan zat pati. Serat terdiri dari selulosa, hemiselulosa, pektin, dan lignin. Serat ini sangat baik untuk membuat seseorang cepat kenyang, karna jumlahnya banyak, 
cepat mengembang dan memenuhi saluran cerna. Ada serat yang cepat larut dalam air, disebut soluble fiber. Serat ini bias mengikat kolesterol atau lemak, lalu membuangnya keluar tubuh. Makanan serat juga membuat perut kenyang, pengosongan di perut lebih lambat, sehingga gula darah lambat naiknya. Serat lainnya sukar larut Namanya insolue fiber, makanan serta seperti ini biasanya bekerja baik di usus besar. Pembuangan tinja menjadi lancer (Tandra dkk, 2016).

\section{Asupan Magnesium}

Tabel 3. Asupan Magnesium Pasien Diabetes Mellitus Tipe 2

\begin{tabular}{ccc}
\hline Asupan Magnesium & $\mathrm{n}$ & $\%$ \\
\hline Baik $(350 \mathrm{mg})$ & 14 & 41 \\
Kurang $(<350 \mathrm{mg})$ & 20 & 59 \\
\hline Total & 34 & 100
\end{tabular}

Tabel 3 menunjukan bahwa ada sebanyak 14 responden (41.2\%) memiliki asupan magnesium yang baik dan 20 orang responden (58.8\%) memiliki asupan magnesium kurang. Menurut AKG tahun 2013 konsumsi magnesium yang baik adalah $350 \mathrm{mg}$.

Magnesium memegang peranan penting dalam lebih dari tiga ratus jenis system enzim di dalam tubuh. Magnesium bertindak dalam semua sel jaringan lunak sebagai katalisator dalam reaksi-reaksi biologic termasuk reaksi-reaksi yang berkaitan dengan metabolism energi, karbohidrat, lipida, protein, dan asam nukleat serta dalam sintesis, degradasi, stabilisasi bahan gen DNA. Sumber utama magnesium adalah sayuran hijau, serealia tumbuk, biji-bijian dan kacang-kacangan. Daging, susu dan hasilnya serta cokelat juga merupakan sumber magnesium yang baik (Almatzier, 2004). Sumber-sumber magnesium yang unggul terdapat pada sayuran yang berwarna hijau. Semakin gelap warnanya, kandungan magnesiumnya semakin tinggi. Paprika dan polong-polongan, seperti buncis, kacang Panjang, kedelai dan kapri juga merupakan sumber magnesium yang baik (Indah, 2012).

\section{Karakteristik Variabel}

Tabel 4. Karakteristik Variabel

\begin{tabular}{lccccc}
\hline \multicolumn{1}{c}{ Variabel } & Mean & Median & Std Dev & Min & Max \\
\hline As.Serat & 21.67 & 22.00 & 3.96 & 13.00 & 28.00 \\
As.Magnesium & 315 & 320 & 5.92 & 150 & 415 \\
Kadar GDP & 171 & 151 & 66.1 & 80 & 320 \\
& & & & & \\
\hline
\end{tabular}

Subjek dalam penelitian ini mempunyai asupan serat rerata 21.67 dengan standar deviasi 3.96, asupan magnesium rerata 315 dengan standar deviasi 5.92 dan kadar glukosa darah rerata 171 dengan standar deviasi 66.1.

\section{Hubungan Asupan Serat Dengan Kadar Gula Darah Puasa}


Tabel 5. Hubungan Asupan Serat dengan Kadar Gula Darah Puasa Pasien

Diabetes Mellitus Tipe 2

\begin{tabular}{cccc}
\hline & \multicolumn{3}{c}{ Kadar Gula Darah Puasa } \\
mg/dl & & \\
\cline { 2 - 3 } Asupan Serat & Tinggi & Normal & \\
& $(126)$ & $(80-125)$ & \\
\cline { 2 - 4 } & $\mathrm{n}$ & $\mathrm{n}$ & 0,013 \\
\hline Baik $(>25 \mathrm{~g})$ & 12 & 9 & \\
Kurang $(<25 \mathrm{~g})$ & 0 & 22 & \\
\hline Total & 12 & & \\
\hline
\end{tabular}

Fisher's Exact Test

\section{Hubungan Asupan Magnesium Dengan Kadar Gula Darah Puasa}

Tabel 6. Hubungan Antara Asupan Magnesium Dengan Kadar Glukosa Darah Puasa

\begin{tabular}{|c|c|c|c|}
\hline \multirow[b]{2}{*}{$\begin{array}{l}\text { Asupan } \\
\text { Magnesium }\end{array}$} & \multicolumn{2}{|c|}{ Kadar Gula Darah Puasa } & \\
\hline & $\begin{array}{r}\text { Tinggi } \\
(126)\end{array}$ & $\begin{array}{r}\text { Normal } \\
(80-125)\end{array}$ & \\
\hline & $\mathrm{n}$ & $\mathrm{n}$ & \\
\hline Baik $(>350 \mathrm{mg})$ & 15 & 5 & 0.16 \\
\hline Kurang $(<350 \mathrm{mg})$ & 7 & 7 & \\
\hline Total & 12 & 22 & \\
\hline
\end{tabular}

Fisher's Exact Test

\section{PEMBAHASAN}

Hasil penelitian menunjukkan bahwa dari 34 responden di RSU GMIM Pancaran Kasih terdapat hubungan yang bermakna. Dimana hasil uji Fisher exact test (exact sig 2) diperoleh tingkat signifikasi menunjukkan nilai $p<0,05$, nilai tersebut menunjukkan bahwa $\mathrm{H}_{\mathrm{a}}$ diterima yang artinya ada hubungan yang bermakna antara asupan serat dengan kadar gula darah puasa pasien Diabetes mellitus tipe 2 yang dirawat inap RSU. GMIM Pancaran Kasih Manado. Kekuatan hubungan antara kedua variabel lemah, tetapi ara hubungan menunjukkan tanda negative yang berarti semakin tinggi kadar gula darah maka semakin rendah konsumsi serat dari sampel. Adanya hubungan asupan serat dengan kadar gula darah dalam penelitian ini dapat dijelaskan bahwa dengan konsumsi serat sesuai kebutuhan dapat menimbulkan rasa kenyang akibat masuknya karbohidrat kompleks yang menyebabkan menurunnya selerah makan dan akhirnya menurunkan konsumsi makan, disamping itu serat juga mengandung kalori rendah serta kandungan indeks glikemiknya juga rendah sehingga dapat menurunkan kadar gula darah dalam tubuh. Serat termasuk dalam jenis karbohidrat kompleks sehingga serat baik dikonsumsi oleh penderita diabetes mellitus. Serat makanan merupakan bagian yang dapat dimakan dari tanaman atau karbohidrat analog yang retensi terhadap pencernaan dan absopsi pada usus halus dengan fermentasi lengkap atau partial pada usus besar (Idris, 2014). Hasil penelitian ini sejalan dengan hasil penelitian yang dilakukan oleh Fitri dan Wirawani (2012) 
dengan sampel sebanyak 46 orang yang mmenyatakan bahwa terdapat hubungan yang bermakna antara asupan serat dengan kadar Gula Darah Puasa (GDP).

Penelitian ini menunjukkan adanya kecederungan terbalik antara asupan magnesium dengan kadar glukosa darah, Dimana nilai Uji Fisher's Exact Test $P=>0.05$ dengan kesimpulan bahwa tidak terdapat hubungan yang bemakna antara asupan magnesium dengan kadar glukosa darah. Selain itu, penelitian ini menunjukkan bahwa responden yang memiliki asupan magnesium kurang dengan kadar glukosa darah tinggi terdapat 16 responden. Ini disebabkan karena pasien memiliki nafsu makan yang kurang dibandingkan sebelum masuk rumah sakit.

Berdasarkan teori magnesium merupakan salah satu mikromineral yang memegang peranan penting pada homeostasis glukosa dan kerja insulin. Magnesium ini juga merupakan kofaktor untuk berbagai enzim yang melibatkan metabolism glukosa khususnya yang menggunakan ikatan phospat (Yenny,2011). Penelitian invitro menunjukkan bahwa magnesium memiliki peranan penting dalam aksi insulin. Magnesium sangat penting sebagai kofaktor pada semua reaksi transfer ATP. Hal tersebut mengidentifikasi bahwa magnesium memiliki peranan dalam phosphorilasi reseptor insulin, dimana magnesium intraseluler dapat menyebabkan efek fungsi tirosin kinase pada reseptor insulin dan berhubungan dengan penurunan kemampuan insulin untuk menstimulasi pengambilan glukosa pada jaringan yang sensitive insulin. Hal tersebut dapat mengakibatkan terjadinya resistensi insulin (Handayani, 2014).

Penelitian ini sejalan dengan penelitian Yenny dan Suatika (2011) dalam penelitian ini di dapatkan kecenderungan korelasi terbalik antara Magnesium serum dengan resistensi insulin $(r=-0.10)$. Setelah dianalisis ternyata korelasi tersebut tidak bermakna signifikan $(p=0.642)$.

\section{KESIMPULAN}

Asupan serat dari responden masih tergolong rendah yaitu sebanyak 25 orang (73,5 \%), demikian juga dengan asupan magnesium responden sebagian besar masih rendah yaitu sebanyak 20 orang (58.8\%), dan kadar gula darah puasa responden sebagian besar memiliki kadar gula darah puasa tidak terkendali $(\geq 126$ $\mathrm{mg} / \mathrm{dl}$ ) sebanyak 22 orang sampel $(64,7 \%)$. Terdapat hubungan yang bermakna antara asupan serat dengan kadar gula darah pasien Diabetes Mellitus.

\section{DAFTAR PUSTAKA}

Almatsier, S. (2006). Penuntun Diet Edisi Baru. PT Gramedia Pustaka Utama. Jakarta.

Amanina, A., Raharjo, B., Farid Setyo, N. (2015). Hubungan AsupanKarbohidrat Dan Serat Dengan Kejadian Diabetes Melitus Tipe II Di Wilayah Kerja Puskesmas Purwosari Surakarta. Surakarta. Diakses melalui http://eprints.ums.ac.id/37865/1/naskah\%20publikasi\%20baru\%202.pdf.

Ariani, S. (2016) Stop Gagal Ginjal Dan Gangguan Ginjal Lainnya. Istana Media. Yogyakarta 
Arisman, (2013). Obesitas,Diabetus Melitus,\& Dis/pidemia, Buku Kedokteran EGC. Jakarta.

Anugrah Lindah Mutiara, (2017). Pengaruh Pemberian Vitamin C, Vitamin E, Dan Kromium (Cr3+) Terhadap Kadar Insulin Tikus Wistar Yang Diinduksi Aloksan Di Surabaya, Medical and Health Science Journal. Vol. 1, No. 1. Manado. Diakses tanggal 19 juli 2017.

Astawan, M.(2008). Warna-warni Makanan. PT Gramedia Pustaka Utama.Jakarta. Beack, M. (2011). IImu Gizi dan Diet. C.V Andi OFFST. Yogyakarata.

Betteng, R., Pangeman, D., Malayu, N. (2014). Analisis Faktor Resiko Penyebab Terjadinya Diabetes Melitus Tipe 2 Pada Wanita Usia Reproduktif Di Puskesmas Wonasa, Jurnal e-Biomedika (Ebm). Volume 2, Nomor 2. Manado. Diakses tanggal 12 April 2017.

Devi, N. (2010). Nutrition and Food Gizi Untuk Keluarga. Buku Kompas. Jakarta.

Departemen Gizi Dan Kesehatan Masyarakat.2007. Gizi Dan Kesehatan Masyarakat. PT RAJAGRAFINDO.Yogyakarta

Dr Adi Sucahyono. (2009). Merencanakan Jenis Kehamilan Anak. PT Elex Media Komputindo. Jakarta

Faradita, A dkk. (2014). Hubungan Asupan Magnesium Dan Kadar Glukosa Darah Puasa Pasien Rawat Jalan Diabetes Melitus Tipe 2 Di RSUD Al-Ihsan jawa barat, IImu Gizi Kedokteran Universitas Brawijaya. Volume 1, Nomor 2, September 2014. Diakses tanggal 10 maret 2017.

Fitri, RI dan Wirawanni, Y. (2012). Asupan Energi, karbohidrat, Serat, Beban Glikemik, Latihan Jasmani dan kadar Gula Darah Pada Pasien DM Tipe 2. Media Medika Indonesia. Volume 46, No. 2. Semarang. Diakses melalui http://ejournal.undip.ac.id/index.php/mmi/article/view/4273.

Hasdiana. (2012). Diabetes melitus (Pada orang dewasa dan anak-anak dengan solusi herbal). Nuha Medika. Yogyakarta.

Helmyati S dkk, (2014). Interaksi Obat dan Makanan, Gajah Mada University Press.Yogyakarta.

Idris M, Jafar N, Indrisasari, (2014). Pola Maka Dengan Kadar Glukosa Darah Pada Pasien Dm Tipe. Jurnal MKMI. Makasar.

Irianto, K. (2014). Epidemiologi Penyakit Menular dan Tidak Menular, Alfabeta, Bandung.

Indah, Y. (2012). Bebas Diabetes Tipe-2, PT AgroMedia Pusataka, Jakarta

Kurniadi, H \& Nurrahmani, U. Stop Diabetes Hipertensi Kolestero Tinggi Jantung Koroner, Istana Media, Yogykarta.

Marya, RK. (2013). Buku Ajar Patofisisologi Mekanisme terjadinya Penyakit. Binarupa Aksara Publisher. Yogyakarta.

Mihardja L., (2009). Maj Kedokt Indon . Volume 59, Nomor 9. Manado

Pangkalan Ide, (2007) Seri Diet Korektif. PT Elex Media Komputindo. Jakarta

PERKENI, (2011). Persatuan Endokrin Indonesia. Jakarta 